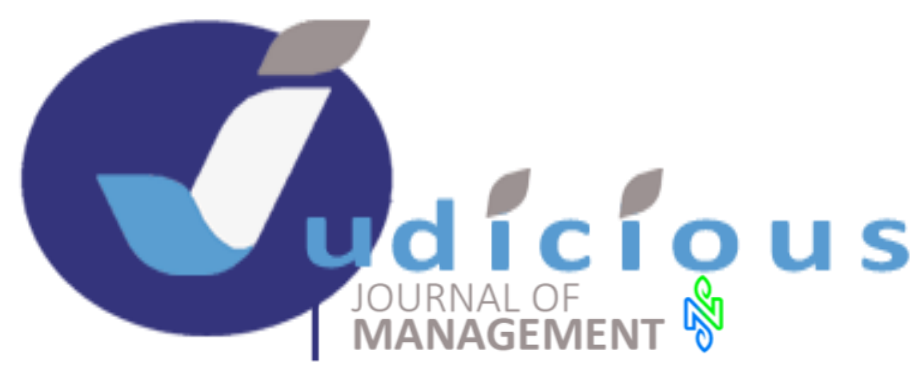

\title{
SIGNIFICANCE BETWEEN THE COVID-19 PANDEMIC REGULATION AND ORGANIZATIONAL CLIMATE WITH EXCELLENT SERVICE AS INTERVENING ON PRODUCTIVITY OF VOCATIONAL HIGH SCHOOL EDUCATION IN BOGOR REGENCY
}

\author{
Deswita \\ STKIP Kusuma Negara \\ Indonesia \\ deswita@stkipkusumanegara.ac.id
}

\author{
Lubban Anwari Alhamidi \\ Universitas Indraprasta PGRI \\ Indonesia \\ lubbanalhamidi@gmail.com
}

\begin{abstract}
This study aims to determine the relationship between organizational climate and the Covid-19 pandemic with excellent service as an intervening on the productivity of vocational high school education in Bogor Regency. The method used in this study is a quantitative research method. The sampling technique in this study used a purposive sampling technique involving 100 educational activists such as educators, students, vice principals to principals at 20 public and private vocational high schools in Bogor Regency. The instruments used in this research are the organizational climate scale, the Covid-19 pandemic and the excellent service scale and the education productivity scale. Analysis of the data used is analysis. The analysis test in this study will test normality, linearity, and simple regression using intervening or path analysis. The correlation coefficient value generated based on the analysis of the results that have been carried out shows the significance value of Variable X1 (Organizational Climate) of 1.00 greater than 0.05 and X2 (Covid-19 Pandemic Regulations) and Variable Z (Excellent Service) of 0.000 more smaller than 0.05. This means that X1 has no significant effect on the Y variable (Vocational High School Productivity) while the X2 and Z variables have a significant effect on the Y variable (Vocational Productivity).
\end{abstract}

Keywords: organizational climate, productivity, education, Covid-19 pandemic, service excellent

\section{INTRODUCTION}

Various types of Vocational High Schools (SMK) in Bogor Regency, ranging from State Vocational Schools to private Vocational High Schools recognize that various resources from inputs to outputs owned by each Vocational School are very important to determine the success and progress of vocational education productivity. Therefore, every academic community, especially the management of SMK, needs to optimize and empower all the resources in their respective schools; one of the resources included is human resources in order to maintain the continuity of the company's life in the future. Human resources included in the company are employees, someone who uses his abilities and energy to get a reward in the form of wages or compensation in the form of financial or non-financial from employers or work superiors. Zulkarnain (2011) explains that the human element, namely workers or members of the organization, is very important in running the organization. The role of human resources has the meaning as a form of ability to carry out the duties optimally given by the company in accordance with its main duties and functions and includes all activities within the company from the 
planning, organizing, implementing activities to evaluating the results of the activities that have been carried out. (Swasto, 2011).

There are many facilities provided by the management team of vocational high schools so that teaching and learning activities can continue to improve in the future. One of the other facilities provided by SMK is related to the work environment, namely students and educators must feel comfortable and happy to work in these schools, and this is because the various components in various SMKs give a good impression when they work. Examples of the environment they feel comfortable in are co-workers and superiors who have mutual help, tolerance, kindness and fun, besides that the place where they do work is also very in accordance with their respective learning schedules, as well as various other facilities from vocational schools that support in improving the quality of learning in the future. The quality of learning is the intensity of systemic and synergistic linkages between teachers, students, learning climate, and learning media in producing optimal learning processes and outcomes in accordance with curricular demands (Mariani in Haryati \& Rochman, 2012: 2). According to Mariani, operational quality of learning can be defined as the intensity of systemic and synergistic linkages between teachers, students, learning climate, and learning media in producing optimal learning processes and outcomes in accordance with curricular demands (Haryati \& Rochman. 2012: 2). According to Daryanto, the quality of learning is a level of achievement of the initial learning objectives including art learning, in achieving these goals in the form of increasing knowledge, skills and developing student attitudes through the learning process in class (Prasetyo, 2013: 12).

The quality of learning has indicators according to the Ministry of National Education in Prasetyo (2013: 13), including:

1. Learning behavior of educators (teachers)

Skills in teaching a teacher show the general characteristics of a person related to knowledge and skills that are manifested in the form of action.

2. Student behavior or activities

There are many activities that students can do at school. School activities are not only studying, reading books, taking notes or listening to teachers teaching. Student activities can be in the form of activities outside the classroom, extracurricular or other activities.

3. Learning climate

The learning climate can be in the form of a conducive classroom atmosphere and a comfortable school atmosphere.

4. Learning materials

Quality learning materials can be seen from their compatibility with learning objectives and competencies that must be taken.

5. Learning media

Learning media creates an active learning atmosphere, facilitating the process of interaction between students and teachers, students and students, students and experts in relevant fields of science.

6. Learning system

The learning system in schools is able to show its quality if the school emphasizes the characteristics of its superiority, has emphasis and the specificity of its graduates.

The academic community will carry out their respective rights and obligations better because they feel that the company provides a good quality of work life for employees.

The dimensions of teacher professional performance are first, the dimension of learning planning, with indicators: reviewing the syllabus, preparing lesson plans (RPP), developing learning media, determining and compiling the second evaluation instrument, dimensions of learning implementation, with indicators: explaining learning objectives, delivering material in accordance with learning objectives, providing examples according to students' thinking, utilizing various learning resources, and managing classes interactively and the three dimensions of learning evaluation, with indicators: making corrections to student answers, analyzing the achievement of student learning outcomes, compiling reports on learning outcomes, and conducting follow-up or improvement. 
Another factor that may influence teacher performance is the organizational climate. The study of organizational climate is one of the studies that emerged in the effort of how a school administrator/manager develops patterns of social interaction so that the goals of the organization can be achieved. Keith Davis defines organizational climate as "the human environment whitin the organization's employees do their work". (Triatna, C. 2015).

Organizational climate as a working condition that is physical and non-physical from the work environment that also influences behavior and which is a motivational factor that needs to get the attention of every leader in the organization (Siagian S.P., 2002). Brief suggests that there are four factors that support the school climate, namely a physical environment that is supportive and conducive to learning, a social environment that encourages communication and interaction, an affective environment that encourages a sense of ownership and self-confidence, and an academic environment that encourages learning and self-fulfillment (Triatna, C. 2015). Stringer (2015) suggests that there are five factors that influence the climate of an organization, namely the external environment, strategy, leadership practices, organizational arrangements, and organizational history. Each of these factors is very decisive; therefore, people who want to change the climate of an organization must evaluate each of these factors. The five factors are:

1. External Environment.

The same industry or business has the same general organizational climate. For example, the general organizational climate of insurance companies is generally the same, as well as the organizational climate of government, elementary schools, or palm oil industry companies in Indonesia, which have the same general climate. The commonality of these general factors is due to the influence of the organization's external environment.

2. Organizational Strategy.

The performance of a company depends on the strategy (what it strives to do), the energy possessed by employees to carry out the work required by the strategy, and the environmental factors that determine the energy level. Different strategies give rise to different patterns of organizational climate. Strategy affects the organizational climate indirectly.

3. Organizational arrangements.

Organizational settings have the strongest influence on organizational climate. Imam Sholikhul Hadi

4. The Power of History.

The older the age of an organization, the stronger the influence of its historical power. These influences are in the form of traditions and memories that shape the expectations of organizational members and have an influence on the organizational climate.

5. Leadership.

The leader's behavior affects the organizational climate which then encourages employee motivation. Employee motivation is the main driver of performance.

The government or education stakeholders face the challenges of unusual learning patterns due to Covid-19. Educators must rack their brains to change the face-to-face learning model into a network platform (online) or from offline to online. Another challenge is to improve the ability of teachers, lecturers, and students to utilize technology in teaching and learning activities. The limitations of internet network infrastructure, the absence of computer equipment, teachers who stutter in information technology, assistance to students while studying at home are no less complicated challenges.

Lussier (2017) divides organizational climate into 7 aspects, namely:

1. Structure

This aspect illustrates that all employees have been well organized, have regulations that must be obeyed, and have clarity about the roles and responsibilities of each employee's work.

2. Responsibility

The level of supervision in the organization imposed by superiors to subordinates, then felt by employees. In addition, the tasks and jobs assigned are the responsibility of each employee. 
3. Rewards

Awards given by the company to employees such as compensation, giving praise and feedback when completing work so that employees will feel recognized for their existence in the company.

4. Warmth

This aspect relates to the atmosphere and interactions in the workplace, good relations between employees and superiors will create friendship, communication, tolerance, and a comfortable working atmosphere.

5. Support

Support is something related to the implementation of organizational tasks, the support provided can be in the form of feelings of mutual help between superiors and subordinates, trust support from colleagues and superiors, and a sense of mutual need between superiors and subordinates.

6. Organizational identity and loyalty

This aspect relates to the feeling of pride shown by employees through loyalty and commitment when they work in the company and adherence to the achievement of company goals.

7. Risk

Opportunities for employees to take risks when carrying out tasks assigned by the company.

Gunaraja \& Venkatramaraju, (2013) explain in their research that there is a significant relationship between organizational climate and the quality of work life of employees. Furthermore, Idrus (2006) also said that the environment that can foster cultural and social in the company or called the organizational climate can determine the quality of a person's work life. Based on this phenomenon, it was found that several factors were able to provide educational productivity starting from the inputprocess period to the output for the better, in this case the management of SMK also created a good organizational climate so that the authors consider that these factors need to be studied further so that The quality of learning in Bogor Regency Vocational Schools can be maintained or further improved. In addition, by looking at the importance of the organizational climate and Vocational High School Productivity in accordance with the expectations of the entire academic community, it can determine the success of the performance of a SMK.

During the Covid-19 pandemic, which is currently still endemic in the world, schools are forced to be closed for quite a long time, it is not even known when it will end. Until now, in July 2021, which has passed twice the commemoration of the national education day, it has been more than a year since school was closed, without any teaching activities, or direct interaction between teachers and students. The learning model changes instantly without proper preparation. Some students may feel happy because they don't have to get up early to go to school, teachers may also get more time to do other things because they don't have to go to school either. Some of the parents may have felt a tremendous shock because they had to have a new obligation to be a teacher as well as a supervisor for their children while studying at home.

The drastic change in the current learning model, without adequate preparation, certainly has consequences on the results achieved. In other words, equal distribution of quality becomes difficult to realize. For schools located in urban areas, with the availability of good internet network facilities, the ownership of gadgets or laptops in each student is certainly felt equally for all students. Even if there is none, students can still access them through existing internet cafes, then of course online-based learning models are not a problem.

Different things may be experienced by schools in areas whose areas have difficulty accessing the internet network, for example in a sub-district city, internet networks are available and can still be used. However, not all students who attend school in the sub-district are domiciled in the sub-district city, there are times when their residences are spread out in remote villages where the internet network is sometimes unstable. The next problem is that not all students have devices that support virtual or online learning methods. So that the automatic online-based distance learning model with internet technology is becoming more difficult to implement optimally. Based on the results of observations made by the author, it shows a condition that not all students can be active in the current learning model. Various efforts have, of course, been made by the teachers, starting from preparing material which is 
then delivered in the form of learning videos which are then uploaded on social applications such as YouTube, to preparing other assignments and then sharing them through the class WhatsApp group. But in fact only a few active students appeared and some other students had no news at all. This may be due to the students' residences in villages with internet access and inadequate facilities and infrastructure.

Due to the Covid-19 emergency, another reason that emerged was the policy that required schools to apply the distance learning method in which teaching and learning activities were carried out from home using virtual classes, making it difficult for students in remote areas to have access into the current learning model.

Distance learning that is currently being implemented also makes the exam in determining student graduation another stumbling block in measuring the quality of education. Without exams, of course, it becomes difficult to assess the success of students in mastering their lessons.

Based on this, it attracted the attention of the author to study further about the relationship between organizational climate and various regulations during the Covid-19 Pandemic with excellent service (service excellent) as an intervening at Vocational High Schools in Bogor Regency.

There are three hypotheses to be tested in this study, namely:

1. H1: There is a relationship between organizational climate and the productivity of vocational high school education in Bogor Regency.

2. H2: There is a relationship between organizational climate and the Covid-19 pandemic with excellent service as an intervening on the productivity of vocational high school education in Bogor Regency.

3. H3: There is a relationship between climate and excellent service for vocational high school education in Bogor Regency.

4. H4: There is a relationship between the Covid-19 pandemic and the excellent service of vocational high school education in Bogor Regency.

5. H5: There is a relationship between service excellence and the productivity of vocational high school education in Bogor Regency.

\section{METHOD}

This research uses correlational quantitative research. This is in line with the purpose of this study, which is to find out the relationship between climate and various regulations during the Covid19 pandemic with excellent service as an intervening at Vocational High Schools in Bogor Regency. Then the numerical data in this study was obtained by measuring the variable scale and then processed using the SPSS version 22.0 for windows program. The sampling technique used by the researcher is purposive sampling technique. The criteria for obtaining a representative sample of the entire population studied were all selected academics from 20 state and private vocational schools in Bogor Regency. Based on this, the researchers used 100 selected academic community members, each of which was 1 teacher, student, vice principal and principal at 20 public and private vocational high schools in Bogor Regency who were the respondents/sample in this study. The instrument used in this research is in the form of a questionnaire or questionnaire that uses a Likert scale. The analysis test in this study will test normality, linearity, and simple regression using intervening or path analysis.

\section{RESULTS AND DISCUSSION}

\section{Results}




\section{Hypothesis testing}

The level of significance value used is 0.05 . If the significance value is more than 0.05 ( $p>0.05$ ), then $\mathrm{H} 0$ is accepted and $\mathrm{H} 1$ is rejected, which means that there is no relationship between the independent variable and the dependent variable. On the other hand, if the significance value is less than 0.05 ( $\mathrm{p}<0.05)$, then $\mathrm{H} 0$ is rejected and $\mathrm{H} 1$ is accepted, which means that there is a relationship between the independent variable and the dependent variable. The following are the terms of interpretation in the correlation coefficient:

\section{Table 1. Interpretation of Correlation Coefficient}

\begin{tabular}{rc}
\hline Coefficient Interval & Relationship Level \\
$0,00-1,99$ & Very low \\
$0,20-0,39$ & Low \\
$0,40-0,59$ & Enough \\
$0,60-0,79$ & Strong \\
$0,80-1,00$ & Very Strong \\
\hline Source: Sugiyono (2010)
\end{tabular}

The results of the path 1 and path 2 coefficient tests in this study are:

Path Coefficient Test 1

Table 2. Path Coefficient Test 1 (Significance)

\begin{tabular}{|c|c|c|c|c|c|c|}
\hline \multirow{3}{*}{\multicolumn{2}{|c|}{ Model }} & \multicolumn{5}{|c|}{ Standardized } \\
\hline & & \multicolumn{2}{|c|}{ Unstandardized Coefficients } & \multirow{2}{*}{$\frac{\text { Coefficients }}{\text { Beta }}$} & \multirow[b]{2}{*}{$\mathrm{t}$} & \multirow[b]{2}{*}{ Sig. } \\
\hline & & $\mathrm{B}$ & Std. Error & & & \\
\hline \multirow[t]{3}{*}{1} & (Constant) & 5.925 & 2.145 & & 2.763 & .007 \\
\hline & Organizational Climate & .051 & .049 & .096 & 1.042 & .300 \\
\hline & Covid-19 pandemic & .152 & .035 & .401 & 4.331 & .000 \\
\hline
\end{tabular}

Referring to the regression output of model 1 in table 2, it can be seen that the significance value of Variable X1 (Organizational Climate) of 0.300 is greater than 0.05 and X2 (Covid-19 Pandemic Regulation) of 0.000 is smaller than 0.05 . This means that $\mathrm{X} 1$ has no significant effect on the $\mathrm{Y}$ variable (Vocational High School Productivity) while the X2 variable has a significant effect on the Y variable (Vocational Productivity).

Table 3. Path Coefficient Test 1 (Model Summary)

\begin{tabular}{|c|c|c|c|c|}
\hline Model & $\mathrm{R}$ & R Square & $\begin{array}{c}\text { Adjusted R } \\
\text { Square } \\
\end{array}$ & $\begin{array}{l}\text { Std. Error of the } \\
\text { Estimate }\end{array}$ \\
\hline 1 & $.422^{\mathrm{a}}$ & .178 & .161 & .813 \\
\hline
\end{tabular}

The value of R-Square in table 3 is 0.178 . This means that the contribution of $\mathrm{X} 1$ and $\mathrm{X} 2$ to $\mathrm{Y}$ is $17.8 \%$ while the remaining $82.2 \%$ is the contribution of other variables not included in the study. As for the value of $1=(1-0.178)=0.906$. So that the path diagram model 1 is obtained as follows: 


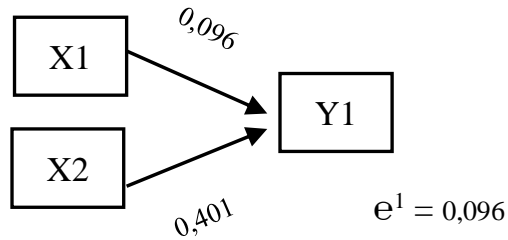

Source: Primary Data Processing Results Using SPSS 22.00 (2021)

Figure 1. R-Square Line 1

Path Coefficient Test 2

Table 4. Path Coefficient Test 2 (Significance)

\begin{tabular}{|c|c|c|c|c|c|c|}
\hline \multirow[b]{2}{*}{ Model } & & \multicolumn{5}{|c|}{ Standardized } \\
\hline & & B & Std. Error & $\frac{\text { Coefficients }}{\text { Beta }}$ & $\mathrm{t}$ & Sig. \\
\hline 1 & (Constant) & $1.279 \mathrm{E}-13$ & .000 & & .000 & 1.000 \\
\hline & Organizational Climate & $2.800 \mathrm{E}-16$ & .000 & .000 & .000 & 1.000 \\
\hline & Covid-19 pandemic & 1.000 & .000 & 2.639 & 82019289.205 & .000 \\
\hline & Excellent service & -1.000 & .000 & -2.407 & -75109219.046 & .000 \\
\hline
\end{tabular}

a. Dependent Variable: Vocational High School Productivity Source: Primary Data Processing Results Using SPSS 22.00 (2021)

Referring to the output of regression model 2 in table 4, it can be seen that the significance value of Variable X1 (Organizational Climate) is 1.00 greater than 0.05 and X2 (Covid-19 Pandemic Regulation) and Variable Z (Excellent Service) is 0.000 smaller than 0.05. This means that X1 has no significant effect on the $\mathrm{Y}$ variable (Vocational High School Productivity) while the $\mathrm{X} 2$ and $\mathrm{Z}$ variables have a significant effect on the $\mathrm{Y}$ variable (Vocational Productivity).

Table 5. Path Coefficient Test 2 (Model Summary)

\begin{tabular}{lcccc}
\hline & & & Adjusted R & \multicolumn{2}{c}{$\begin{array}{c}\text { Std. Error of the } \\
\text { Model }\end{array}$} & $\mathrm{R}$ & $\mathrm{R}$ Square & Square & Estimate \\
\hline 1 & $1.000^{\mathrm{a}}$ & 1.000 & 1.000 & .000 \\
\hline a. Predictors: (Constant), Excellent Service, Organizational Climate, \\
Covid-19 Pandemic \\
Source: Primary Data Processing Results Using SPSS 22.00 (2021)
\end{tabular}

The value of R-Square in table 5 is 0.100 . This means that the contribution of the influence of $\mathrm{X} 1$ and $\mathrm{X} 2$ on $\mathrm{Y}$ is $10 \%$ while the remaining $90 \%$ is the contribution of other variables not included in the study. As for the value of $1=(1-0,100)=0,948$. So that the path diagram model 1 is obtained as follows:

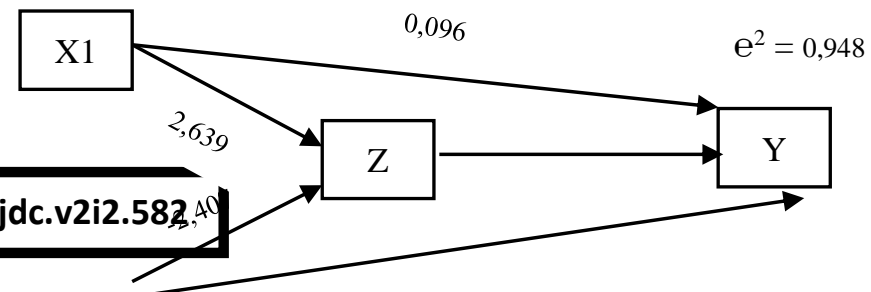


Figure 2. R-Square Line 2

Source: Primary Data Processing Results Using SPSS 22.00 (2021)

\section{Discussion}

This study aims to determine the relationship between organizational climate and regulation of the Covid-19 pandemic on the productivity of vocational education in Bogor Regency. Initially, technology was created to facilitate every human activity. Technology was born from human thought that tried to simplify its activities which were then applied in life. Now technology has developed rapidly and is increasingly sophisticated along with the times so that there are additional technological functions that increasingly spoil human life. One example Today's sophisticated facilities are cellphones (Haryono, Ariwibowo, Djuhartono, 2019). The results of research that has been carried out on 100 academics from 20 vocational schools in Bogor Regency, through the help of the SPSS version 22.0 for windows program using regression testing shows the significance value of Variable X1 (Organizational Climate) of 0.300 greater than 0.05 and X2 (Pandemic Regulations). Covid-19) of 0.000 is less than 0.05 . This means that $\mathrm{X} 1$ has no significant effect on the $\mathrm{Y}$ variable (Vocational High School Productivity) while the $\mathrm{X} 2$ variable has a significant effect on the $\mathrm{Y}$ variable (Vocational Productivity). This is in line with the results of research conducted by Firmansyah and Kardina (2020), that the policies issued by the government towards the new normal can have a major influence in various aspects, especially in the field of education which can have an influence in managing schools and students towards the new normal. The school and the surrounding community have a give and take relationship. This new normal means living side by side with Covid-19. The Ministry of Education and Culture issued Circular No. 15 of 2020 concerning Guidelines for Organizing Learning from Home in an Emergency Period for the Spread of Covid-19. The decree is very influential for the continuity of education in Indonesia by implementing the new normal. However, the results of this study are not in line with the results of research conducted by Novianto (2014) which states that the influence of organizational climate on school productivity in junior high schools in Cirebon City is strong. This is due to the fact that when research was carried out in the new normal, the organizational climate of various vocational schools in Cibinong Regency almost changed $100 \%$ according to New Normal conditions, namely at least there were many changes in teaching culture from teaching offline (face to face) to online (online/virtual).

Likewise, with the results of subsequent studies in the second path which resulted in a significance value of Variable X1 (Organizational Climate) of 1.00 greater than 0.05 and X2 (Covid19 Pandemic Regulations) and Variable Z (Excellent Service) of 0.000 smaller of 0.05. This means that $\mathrm{X} 1$ has no significant effect on the Y variable (Vocational High School Productivity) while the X2 and $\mathrm{Z}$ variables have a significant effect on the $\mathrm{Y}$ variable (Vocational Productivity). This is in line with the results of research conducted by Munarti, Sudharto, and Abdullah (2016), namely that there is a significant influence between school organizational climate on school performance at SMK Taman Kabupeten Pemalang, meaning that the regression equation for the $\mathrm{X} 2$ variable against $\mathrm{Y}$ is $\mathrm{Y}=3.161$ $+0.208 \mathrm{X} 1$. This regression equation illustrates that fluctuations in school performance are influenced by the ups and downs of the school's organizational climate. In addition, the quality of education services at the Al-Fahmi Integrated Islamic Elementary School in Palu is quite good based on the perceptions of students who have experienced the form of services provided by educators in schools. The results of excellent service at the Al-Fahmi Integrated Islamic Elementary School in Palu in improving the quality of learning can be seen in the achievements of students. Among them are the 
potential and talents of students in winning championships, memorizing 2 juz of the Qur'an when graduating from school and good report cards (Hardianto, 2019).

\section{CONCLUSION}

This study aims to determine the relationship between organizational climate and regulation of the Covid-19 pandemic on the productivity of vocational education in Bogor Regency. Based on the results of the data analysis that has been carried out, it is known that the results of the research in path 1 that X1 (organizational climate) has no significant effect on the Y variable (Vocational High School Productivity) while the X2 variable (Covid-19 pandemic regulation) has a significant effect on the $\mathrm{Y}$ variable (Vocational Productivity). The results of the analysis show that organizational climate has a weak correlation, meaning that the relationship between variables has a negative relationship, so that if the organizational climate of employees is high, the productivity of vocational education in Bogor Regency does not change/remains high. On the other hand, every Covid-19 pandemic regulation issued by the government has a very strong influence, meaning that if every regulatory change issued by the government and the emergence of sufferers from various virus variants and new vaccines from Covid19 are in high conditions, the productivity level of SMKs in the Regency will be high. Bogor has decreased. Vice versa.

\section{Suggestion}

\section{For Vocational High Schools (SMK)}

Vocational schools are expected to be able to pay attention to every Covid-19 pandemic regulation from the latest government and improve a safe and comfortable organizational climate for the entire vocational academic community, because this has an impact on the productivity of Vocational High Schools, especially various Vocational High Schools in Bogor Regency. High work productivity in SMK will make the entire academic community have good performance, so that SMKs in Bogor Regency will also be more developed and advanced in the future.

2. For the SMK Academic Community

For the SMK Academic Community, it is expected to be able to improve and maintain a comfortable, safe and pleasant work environment. Especially the relationship with the SMK managerial team, educators to students who respect each other, help each other, so that the good perception shown by the academic community towards the SMK environment can be well maintained, then this will have an impact on SMK productivity which can improve the performance of the community. academic.

3. For Further Researchers

Future researchers are expected to be able to conduct research with a wider population and research sample in the entire academic community and the shareholders and stakeholders of SMK-SMK in Bogor Regency and outside Bogor Regency and conduct research with different variables.

\section{REFERENCES}

Dixon, J. L., \& Stringer, L. C. (2015). Towards a theoretical grounding of climate resilience assessments for smallholder farming systems in Sub-Saharan Africa. Resources, 4(1), 128-154.

Firmansyah, Y., \& Kardina, F. (2020). Pengaruh New Normal Ditengah Pandemi Covid-19 Terhadap Pengelolahan Sekolah dan Peserta Didik. Buana Ilmu, 4(2), 99-112.

Gunaraja, T. M., \& Venkatramaraju, D. (2013). A study on organisation climate and it impacts on quality of work life in Indian Industry - with reference to Chennai City. Indian Journal of Applied Research, 3(12), 295-297. https://www.worldwidejournals.com/indianjournal-ofapplied-research-(IJAR)/article/a-studyon-organisation-climate-and-it-impacts-onqualityof-work-life-in-indian-industry-with-reference-tochennai-city/MjgxMQ==/ 
Hardianto, M. A. (2019). Bentuk Pelayanan Prima Dalam Meningkatkan Mutu Pembelajaran Di Sekolah Dasar IT Al-Fahmi Palu (Doctoral dissertation, IAIN Palu).

Haryati, T., \& Rochman, N. (2012). Peningkatkan kualitas pembelajaran pendidikan kewarganegaraan melalui praktik belajar kewarganegaraan (Project citizen). CIVIS, 2(2).

Haryono, S., Ariwibowo, P., \& Djuhartono, T. (2019). PKM Ekonomi Produktif Melalui Technopreneurhip Bagi Guru di SMK Bisnis Dan Teknologi. CARADDE: Jurnal Pengabdian Kepada Masyarakat, 2(1), 113-123. https://doi.org/10.31960/caradde.v2i1.250

Lussier, Robert N. (2017). Human Relations in Organizations. New York: McGraw-Hill Education.

Novianto, E. (2014). Pengaruh Kepemimpinan Visioner Kepala Sekolah Dan Iklim Organisasi Sekolah Terhadap Produktivitas Sekolah: Studi pada Sekolah Menengah Pertama di Kota Cirebon (Doctoral dissertation, Universitas Pendidikan Indonesia).

Prasetyo, Hendrawan. (2013). Pengaruh Tingkat Kepuasan Siswa Dan $310 \sim$ Minat Belajar Terhadap Prestasi Belajar Praktek Dan Teori Pada Mata Diklat Body And Painting Di Smk Piri 1 Yogyakarta Tahun 2011/2012 Journal.http://eprints.uny.ac.id/100 40/.

Siagian, S.P. (2002).Manajemen Sumber Daya Manusia. Jakarta: PT. Bumi Aksara.

Swasto, B. (2011). Manajemen sumber daya manusia. UB Press

Triatna, C. (2015). Membangun Komunitas Belajar Profesional Untuk Meningkatkan Mutu Pendidikan di Sekolah. Jurnal Administrasi Pendidikan, 22(1).

Zulkarnain. (2011). Dampak burnout terhadap kualitas kehidupan kerja pada pekerja public service. $338-\quad 345 . \quad$ http://www.researchgate.net/publication/23784144 4_DAMPAK_BURNOUT_TERHADAP_KUALIT AS_KEHIDUPAN_BEKERJA_PADA_PEKERJA_PUBLIC_SERVICE. 